Review Paper

\title{
JUDICIAL AUTHORITY REFORMS IN MEDIEVAL SERBIA, BOHEMIA AND POLAND
}

UDC 340.047(=16) “4/14"

\author{
Aleksandar Đorđević \\ Faculty of Law, University of Niš, Republic of Serbia
}

\begin{abstract}
On the basis of relevant legal history sources, in this paper, the author analyses the attempt to reform the judiciary in the medieval Slavic world. In the $14^{\text {th }}$ century, three important legal codes were enacted in Serbia, Bohemia, and Poland: Dušan's Code, Maiestas Carolina and Statutes of Casimir the Great, respectively. The proclamation of these three codes was the result of strengthening the powers of their rulers: Emperor Dušan, the Bohemian king Charles IV, and the Polish king Casimir. Almost at the same time, these rulers passed very similar legal provisions on the reorganisation of courts.The main idea was to introduce special state judges, with the aim of suppressing and limiting the feudal and other forms of judiciary in their respective states.The reform of courts, the judiciary and court proceedings was part of the prevalent attempts to centralise state authority in the three Slavic states. This process is a phenomenon of substanital relevance in the history of Slavic law, particularly given the fact that it involved the most powerful rulers of these medieval states, who were one another's contemporaries.
\end{abstract}

Key words: Slavic law, Middle Ages, judiciaryreform, ruler, state authority, state judges.

\section{INTRODUCTION}

The rulers of medieval feudal states performed two basic functions without which the organisation of the state could not practically exist: the function of the supreme commander-in-chief and the function of the supreme judicial authority. The entire governmental organisation of the feudal society actually originated from the judicial function of the ruler, and the judiciary was the first and main instrument of maintaining social peace and establishing the legal state.

In medieval times, a very complex and dysfunctional system of judicial authorities and jurisdictions, which was partly interited from the antiquity and partly reorganised in

Received February $7^{\text {th }}, 2018$ / Accepted August $9^{\text {th }}, 2018$

Corresponding author: Aleksandar Đorđević, LL.D., Assistant Professor, Faculty of Law, University of Niš, Trg Kralja Aleksandra 11, 18000 Niš, Republic of Serbia

E-mail: djole@ prafak.ni.ac.rs 
line with the prevailing understanding of the role of the state at that time, was the product of the fragmented feudal society, largely based on privileges and favourism. Such a system was an obstacle and a substantial threat to the strengthened central authority and power of medieval rulers in Serbia, Bohemia and Poland in the mid- $14^{\text {th }}$ century. Thus, at about the same time, the rulers of these three Slavic states enacted legal codes which were aimed at introducing substanital reforms largely pertaining to the organisation of the state in general and the judiciary in particular.

Within a period of only several years apart, the three Slavic rulers - the Polish King Casimir the Great, the Serbian Emperor Stefan Dušan, and the Bohemian King and the German Emperor Charles IV - enacted three monumental legal codes: the unified Statutes of Lesser Poland and Greater Poland (in 1346 and 1347), Emperor Dušan's Code (in 1349 and 1354), and Maiestas Carolina (in the mid-14th century). The tendency towards the centralisation and unification of the judicial system in Russia would ensue only half a century later, at the end of the $15^{\text {th }}$ century, when the Russian Sudebnik (collection of laws) was enacted in 1497 during the reign of the Grand Prince of all Russia, Ivan III Vasilyevich (Ivan the Great).

The courts of large feudal lords who were virtually sovereign rulers in their hereditary estates, the autonomous judicial authorities in medieval towns, mixed courts including and local patrimonial (feudal) tribunals based on the archaic traditions of kinship, tribal customs and territorial communities were entirely incompatible with the new socio-economic, legal and political reality in these Slavic states. The development of monetary economy (commodity for money), trade, mining, and society as a whole generated attempts to reform the organisation of the state authorities in general and the judical authority in particular. During the $14^{\text {th }}$ century, the rulers of Serbia, Poland and Bohemia were the embodiment of the central state authority; as such, they endeavoured to put the organisation of the judiciary under their own control as much as possible. The tendency of "nationalising" different types of courts, such as state, patrimonial (feudal), autonomous and mixed courts, was apparent in these legal codes; regardless of the success it achieved, it was an important stage in the development of the Slavic judicial system.

\section{The Judiciary in Emperor Dušan's Code (Medieval Serbia)}

In the Serbian medieval state, the ruler's judicial authority was inseparable from his legislative and executive authority. The Emperor's Court and the Court at the Emperor's Palace, were the supreme judicial authority in medieval Serbia. The Emperor's Court had exclusive jurisdiction in proceedings dealing with the most serious criminal offences: treason, abduction, murder, aggravated assault and battery, horse theft, brigandry, robbery and land disputes (Jireček, Radonić, 1988: 118; Taranovski, 1996: 705-706; Mirković, 2002: 3-4).

Dušan's Code brought important novelties in the organisation of courts in medieval Serbia. By relying on the Byzantine judiciary model, the legislator envisaged the office of imperial curcuit judges (designated in the Code as "the judges of my Empire") into the Serbian legal system, with the intention to institute a significant redistribution of judicial powers. Bearing in mind that Emperor Dušan's Code was valid in the entire territory of the Serbian medieval state, it is clear that the introduction of curcuit judges into the legal system had an adverse effect on the judicial authority of the feudal lords on feudal lands. 
State (circuit) judges were in charge of adjudicating all disputes among the noblemen, land disputes between a church or a monastery and feudal lords, and disputes between dependants (serfs and slaves) and citizens (Marković, 1986: 45). Unlike the feudal lord in Poland and Bohemia, Serbian feudal lords did not have their own courts; they were under the jurisdiction of the general state courts. In medieval Serbia, during the rule of Emperor Dušan, it was a reflection of the supremacy of the principle of legal state as compared to the principle of class system (Taranovski, 1996: 706).

Considering that the Emperor's circuit judges ("the judges of my Empire") had territorial and subject matter jurisdiction to hear cases and administer justice in assigned regions, this new institution was a threat to the traditional judicial organisation and special jurisdiction of feudal courts and autonomous judicial auhorities. By introducing the judicial office of circuit judges appointed by the Emperor, the legislator intended to establish uniform judicial proceedings in the entire territory of medieval Serbia and thus overcome the existing territorial fragmentation in the feudal society and the inherited personal particularism during proceedings. There is evidence that Emperor Dušan's reform of the legal system was partly aimed at separating the administrative and the judicial authority, given that the the newly-instituted curcuit judges had jurisdiction to adjudicate disputes concerning the so-called "imperial charges". ${ }^{1}$ Numerous provisions of Dušan's Code which prescribed norms about courts and judicial proceedings (e.g.: Articles $89,92,105,171,175$, etc.) envisage that the proceedings were to be conducted before state judges.

According to Dušan's Code, every judge was assigned to hear cases in a particular region or circuit: "Let no man, who is within the jurisdiction of circuit judges whom I the Tsar have appointed, be summoned to trial in my Imperial Court, but let each appear before his own judge so that the matter may be tried according to the law" (Article 178 of Dušan's Code, SASA, 1997: 151 ${ }^{2}$. According to the relevant provisions of the Code, state judges were appointed by the ruler, who also decided on the territorial unit (area, circuit) in which they would be administering justice. Under the influence of Byzantine law, the Code determined territorial jurisdiction of curcuit judges, but there were some differences. In the Byzantine Empire, the Supreme Court was established in Constantinople within the reforms instituted by Emperor Andronicus II in 1269; it included the representatives of the church and the state, which was not the case in medieval Serbia (Marković, 1986: 47). The provisions of Dušan's Code show that state judges did not have the permanent seat of court sessions and proceedings in the assigned regions; instead, they traveled across the assigned territory to hear cases and administer justice: "Let judges go through the land within their jurisdiction, to supervise and do justice to the poor and the needy" (Article 175 of Dušan's Code, SASA, 1997: 153). Purusant to Dušan's Code, state judges had exclusive jurisdiction to adjudicate cases involving the most serious criminal acts, such as: murder (bloodshed), brigandry, theft, aggravated assault and battery, harbouring runaway serfs or slaves, and land disputes (SASA, 1997: 153).

\footnotetext{
${ }^{1}$ The term "imperial debts" refers to the disputes which were excluded from the jurisdiction of other courts and transferred to the exclusive authority of the ruler; it includes cases of murder, land dispute, brigandry, and harbouring aliens, runaway serfs or slaves.

${ }^{2}$ Emperor Dušan's Code, The Serbian Academy of Sciences and Arts (SASA), Belgade, 1997. A translated version of Emperor Dushan's Code is available at: http://www.srpskoblago.org/serbian-history/serbian-medieval-history/rulers/ dushans-code.html (accessed 1.7.2018)
} 
On the other hand, the remaining question is the actual implementation of the provisions envisaged in Dušan's Code, and the overall success of the legislative endevour to reform the Serbian judicial system of the time. As a matter of fact, some historical sources contain reference to other bodies of state authority which preserved their judicial authority well after the office of imperial circuit judges had been introduced. The elaborate Charter issued to the citizens of Dubrovnik in 1349, right after the proclamation of Dušan's Code, as well as the Hilandar Chrysobull of 1355, prescribed the old forms of judicial power, which was vested in the Kephale (the city Governor), Knyaz (Duke) and customs officers. This could be explained either by an assumption that the phrase "judges of my Empire" used in Dušan's Code refered to all existing bodies of judicial authority or by the claim that the legal norm had been undermined under the impact of much more durable and resistent customs and the force of formerly enacted law.

\section{The Judiciary in King Charles' Maiestas Carolina and the Statutes of Casimir the Great}

The process of the centralisation of the state and judicial authorities, which was the main pursuit of Emperor Dušan's Code, was also a prominent feature of some Bohemian and Polish legal history documents which were issued in the mid $-14^{\text {th }}$ century. Being the contemporaries of the Serbian Emperor Dušan, the German Emperor and Bohemian king Charles IV $^{3}$ and the Polish King Casimir the Great, were the exemplary embodiement of imperial power and strong centralised governing authority. Relying on the Church, their skillful diplomatic activity and monetary economy flourishing in wealthy cities, they both passed legal codes which aimed at centralizing and unifying the judicial systems in their respective states (Dvornik, 2001: 88-120). ${ }^{4}$

Unlike Serbia, Bohemia and Poland had feudal class-system courts which had jurisdiction in the proceedings involving feudal lords. Due to this fact, they could not prescribe exclusive jurisdiction of the state court for disputes involving feudal lords, unlike Emperor Dušan.

\section{The Judiciary in King Charles' Maiestas Carolina (Medieval Bohemia)}

Maiestas Carolina, the Code issued by the Bohemian King Charles IV, aimed to strengthen the imperial (state) court and prevent the abuse of judicial authorities in local courts which were still under the control of noblemen (Dvornik, 2001: 103). Charles IV prescribed that more serious criminal offences should be exempt from the jurisdiction of state and provincial courts, and should be adjudicated by the imperial officials, known as "popravci" (Dvornik, 2001: 103). Charles' Code proposed an efficient control of the judicial system by setting up royal clerks and clan elders ("starosta"). The elders, who were appointed by the king, had a significant role during proceedings and in the control of the judiciary. Article 7 of Charles' Code stated: "Hereby, for reasons of ultimate

\footnotetext{
${ }^{3}$ This ruler had two names - King Charles I of Bohemia, and German Emperor Charles IV of Luxemburg .

${ }^{4}$ For more about these two Slavic rulers, see a separate chapter on Charles IV, the Emperor and King of Bohemia, and Casimir the Great, the King of Poland in: Dvornik, 2001: 88-120.

5 This institution is known in the old Bohemian law, written in the co-called Rosenberg Book, a significant historical monument of old Check law. It originated from the term "poprave", which signified the judicial county. In the mid- $13^{\text {th }}$ century, during the rule of Premyslas II, special emissaries and officials of the ruler were assined to control the judiciary in towns, as well as the courts of feudal lords. For more, see: Беляева, 1961: 839.
} 
necessity, we prescribe that the fortified towns shall have the elders who are worthy of that duty; and the border fortifications shall have burgraves, who shall perform their duties in line with the vested authorities and adjudicate cases involving both criminal proceedings and land disputes" (Беляева, 1961: 839). Article 17 of this Code envisaged that all state officials (judges, governors and elders) could be replaced and/or removed from office, which made them dependent on the royal authority (Беляева, 1961: 839).

\section{The Judiciary in the Statutes of Casimir the Great (Medieval Poland)}

The Polish King Casimir the Great seems to have followed the Bohemian example and tried to centralise the judicial system of Poland, to the extent possible. Here, the local authorities were vested in the elders ("starosta"), who were appointed for their offices in the territories of inland cities during the predominance of the Bohemian nobility. The institution of 'elders' proved to be very useful for the interests of the state and subsequent rulers. Casimir the Great prescribed that the elders should try all more serious criminal offences, which were quite common in the disunited feudal Polish state before he came to the throne. The adjudication of serious criminal offences was excluded from the jurisdiction of feudal courts and transferred to the exclusive jurisdiction of royal (state) judges, as representatives and advocates of the interests of the state unity (Любавский, 2004: 344345). In Chapter XIII, the Statutes of Casimir the Great also regulated the place and time of judicial proceedings: "It is known that, according to an old custom, judges conducted the proceedings regardless of time (part of day and hour) so that many of them (judges) commonly appeared in court after lunch; after being well wined and dined, they could hardly focus on trial proceedings. Therefore, in order be able to deliberate on cases at issue with due diligence, at the specific hour and time of day, we hereby prescribe that court hearings and adjudication in trial proceedings shall take place from 9 am to $12 \mathrm{am}$ on the court working days..." (Андреев, 2002: 295).

Pursuant to the Statutes of Casimir the Great, the administration of justice pertaining to the dependent population (serfs) was entrusted to the city administrative centres ("castellany"); thus, this kind of proceedings were excluded from the jurisdiction of feudal courts: "According to the long-standing custom, if a serf kills another serf, he may be exempt from punishment by paying a fine; however, considering that a fine is insufficent punishment for murder, we hereby prescribe as follows: if a serf kills another serf, as punishment for murder he shall pay a fine to the castellany in whose territory he committed the murder, or to another, as prescribed by the the law... And if the murderer does not pay the fine, he shall be apprehended and punished by death" (Андреев, 2002: 299-300). Similar to Emperor Dušan's Code, the Statutes of Casimir the Great also include provision on the royal (state) judges.

In Bohemia and Poland, the process of excluding court proceedings from the jurisdiction of lower feudal courts and transferring them to the jurisdiction of the state court was very similar to the judicial reform of Emperor Dušan. The process was essentially aimed at centralisation and nationalisation of the highly complex and polycentric feudal judiciary, and ultimately aimed at centralisation of the entire state authority. The appointment of special state officials (starosta) to a some extent corresponds to the appointment of state judges ("the judges of my Empire") in the Serbian medieval legal system. 


\section{CONCLUSION}

The supreme judicial authority of rulers in some Slavic medieval states was only in certain epochs similar to the judicial authority of old Russian dukes and Serbian rulers. Observed in its entirety, the ruler's authority in medieval Poland, Bohemia or Croatia did not achieve the scope it had had in Kievan Rus or Serbia. Distinctive social conditions in certain parts of the Slavic territories generated important differences in the governmental structure and legal systems of individual Slavic states. Poland and Bohemia, which predominantly developed under the Germanic influence, were largely fragmented feudal states during the Middle Ages; therefore, their state organisation was in accordance with the relations which were typical for such states. In such a system, the supreme authority belonged to the feudal (patrimonial) lords of the lands, while the rulers had the supreme judicial auhtority only occasionally, depending on many internal and external factors. In Russia, Serbia and Bulgaria, where the Byzantine influence was predominant, the governing power was much stronger and more centralized. Consequently, there were differences in the systems of government of Slavic states, including the judicial systems and judicial power of the central authority.

However, the reforms of very complex medieval judicial system in Bohemia and Poland during the mid-14 $4^{\text {th }}$ century may be viewed as a departure from the feudal state organisation system which, in these two Western Slavic states, exclusively reflected the supremacy of big feudal lords over the ruler. Along with the strengthening of the ruler's authority, there were endevours to reorganise the feudal judiciary in line with the changing socio-economic, cultural and political circumtsnces of the time. The central authority of the ruler was increasingly on the rise due to the overall development of these medieval Slavic states, but also due to the support of certain institutions and social classes. Almost concurrent, these attempts in Serbia, Bohemia and Poland to streghten and centralize the ruler's authority over the state through the reform of the judiciary represents a highly specific phenomenon in social and legal history, as well as in the legal state theory and practice. While these three states were essentially class-based monarchies, the endevours to the reform the judiciary prompted the development of early stages of absolute monarchy. This type of state did not come into being in the Slavic world in the mid- $14^{\text {th }}$ century but at a later period it was established (to some extent) in the Grand Principality of Moscow.

\section{REFERENCES}

Андреев А. Р., (2002), История Польши, (Polish History), Издательство наук, Москва.

Беляева Г. П., (1961), Хрестоматия памятников феодального государства и права стран Европы, Книга Рожмбергская, (Selected Readings from the monumental legal documents of the feudal state and laws in European countries, the Rosenberg Book), Москва.

Дворник Ф., (2001), Словени у европској историји и цииилизаиији (The Slavs in the European History and Civilisation), Clio, Београд.

Јиречек К., Радонић Ј., (1988), Историја Срба II (History of the Serbs II), Просвета, Београд.

Любавский М. К., (2004), История западных славян (History of the Western Slavs), Парад, Москва.

Марковић Б., (1984), Душанов законик, (Dušan's Code), Српска књижевна задруга, Београд.

Тарановски Т., (1996), Историја српског права у Немањићкој држави, Класици југословенског права, Београд.

Законик иара Стефана Душана (1997), Српска академија наука и уметности (САНУ), Београд. (SASA: Emperor Dušan's Code, the Serbian Academy of Sciences and Arts, Belgrade, 1997). 


\section{REFORMA SUDSKE VLASTI U SREDNJOVEKOVNOJ SRBIJI, ČEŠKOJ I POLJSKOJ}

U radu autor na osnovu tekstova relevantnih pravnoistorijskih izvora analizira pokušaj reforme sudstva u srednjovekovnom slovenskom svetu. U Srbiji, Češkoj i Poljskoj u XIV veku doneta su tri pravna zbornika - Dušanov zakonik, Maiestas Carolina i Statuti Kazimira Velikog. Proglašenje ova tri zakonika bilo je uslovljeno jačanjem vladarske vlasti. Car Dušan, češki kralj Karlo i poljski kralj Kazimir doneli su, gotovo u isto vreme, veoma slične odredbe o reorganizaciji sudova. Osnovna ideja bila je uvođenje posebnih državnih sudija, sa ciljem potiskivanja i ograničavanja feudalnog $i$ drugih oblika pravosuđa u svojim državama. Reforma sudova i sudskog postupka bila je deo sveobuhvatnog pokušaja centralizacije državne vlasti u trima slovenskim državama. Takav proces predstavlja fenomen u istoriji slovenskog prava $i$ vezan je za najmoćnije vladare pomenutih država koji su bili $i$ savremenici.

Ključne reči: slovensko pravo, srednji vek, reforma sudstva, vladar, državna vlast, državne sudije.

Proofreading and copy-editing:

Gordana Ignjatović 